\title{
Geophysical methods for detecting shallow sulphide mineralization in the Halifax Formation, Nova Scotia: a reconnaissance study
}

\author{
K. Howells ${ }^{1}$ and D. Fox ${ }^{2}$ \\ 'Ken Howells Geoscience, 27 John Cross Drive, Dartmouth, Nova Scotia B2W 1XI, Canada \\ ${ }^{2}$ Department of Earth Sciences, Dalhousie University, Halifax, Nova Scotia B3H 3J5, Canada
}

Date Received August 16, 1998

Date Accepted November 16, 1998

\begin{abstract}
Construction activities have exposed sulphide-bearing slates of the Halifax Formation in southern mainland Nova Scotia. Under atmospheric conditions the sulphides break down and cause acid rock drainage (ARD) which adversely affects local ecosystems. These effects have been a major problem at the Halifax International Airport, causing fish kills and the expenditure of millions of dollars to ameliorate the ARD. A preferable alternative is to locate areas of sulphide mineralization in the construction area prior to excavation. Concentrated zones of sulphide mineralization can then be avoided, or treatment plans can be formulated in advance. Geophysical surveys provide possible means of detecting sulphides in slates of the Halifax Formation.

To evaluate various geophysical methods, reconnaissance profiles were carried out in two areas near the Halifax International Airport utilizing ground conductivity, magnetic, VLF EM, spontaneous potential, and induced polarization measurements. The conductivity meter selected was specific to "construction depths" (i.e., its exploration depth limit is $6 \mathrm{~m}$ or less). Test pits were dug on one line in each area to sample bedrock coincident with and between conductivity anomalies. Bedrock samples collected in each test pit were analyzed for total sulphur, total carbon, $\mathrm{Fe}^{2+}$, and $\mathrm{Fe}^{3+}$ contents.

On the first grid, increased total sulphur content was measured in rock specimens from a test pit coincident with a large ground conductivity anomaly. In contrast, extremely small total sulphur content was measured in rock specimens from a nearby hole which was deliberately situated where there is no conductivity anomaly. Similar results were obtained from the second grid. Magnetic anomalies are coincident with all but one of the sampled conductivity anomalies, indicative of the presence of pyrrhotite. Combined ground conductivity, magnetic and VLF EM surveys appear to be a practicable method for detecting near-surface sulphide mineralization in the Halifax Formation, and such surveys should be included in the Nova Scotia Environment Act.
\end{abstract}

Les activités de construction ont mis à nu des ardoises sulfurifêres de la Formation d'Halifax dans le sud intérieur de la Nouvelle-Écosse. Dans des conditions atmosphériques, les sulfures se décomposent et causent une exhaure de roches acides (ERA) qui a des effets néfastes sur les écosystèmes locaux. Ces effets ont constitué un problème de grande envergure à l'aéroport international d'Halifax, où ils ont causé la mort de poissons et exigé des investissements de plusieurs millions de dollars pour améliorer l'ERA. Une solution de rechange qu'on préfère consiste à délimiter les zones de minéralisation de sulfures à l'intérieur du secteur de construction avant les travaux de creusage. On peut ensuite éviter les zones concentrées de minéralisation de sulfures ou formuler des plans de traitement à l'avance. Les relevés géophysiques peuvent permettre de détecter les sulfures à l'intérieur des ardoises de la Formation d'Halifax.

Les chercheurs ont, pour évaluer diverses méthodes géophysiques, dressé des profils de reconnaissance dans deux secteurs situés près de l'aéroport international d'Halifax au moyen d'études de polarisation induite, de diagraphie de polarisation spontanée et de conductivité ainsi que de relevés magnétiques et électromagnétiques. Le conductivimètre choisi était spécifique aux " profondeurs de construction " (c.-à-d. que sa limite de profondeur d'exploration est de $6 \mathrm{~m}$ ou moins). Ils ont creusé des trous d'exploration le long d'une ligne dans chaque secteur pour échantillonner le substrat rocheux correspondant aux anomalies de conductivité de même qu'entre celles-ci. Les chercheurs ont ensuite analysé la teneur en soufre total, en carbone total, en $\mathrm{Fe}^{2+}$ et en $\mathrm{Fe}^{3+}$ des échantillons de substrat rocheux prélevés dans chaque trou d'exploration.

Dans le premier quadrillage, les chercheurs ont mesuré la teneur en soufre total des échantillons de roches provenant d'un trou d'exploration correspondant à une anomalie prononcée de conductivité du sol. Par contraste, on a relevé une teneur en soufre total extrêmement réduite dans les échantillons de roches provenant d'un trou à proximité délibérément creusé à un endroit où aucune anomalie de conductivité n'a vait été relevée. On a obtenu des résultats semblables dans le deuxième quadrillage. Les anomalies magnétiques correspondaient à toutes les anomalies de conductivité échantillonnées indiquant la présence de pyrrhotine sauf une. La combinaison des études de conductivité du sol avec des relevés magnétiques et électromagnétiques semble constituer une méthode pratique pour détecter une minéralisation de sulfures à faible profondeur dans la Formation d'Halifax. La Loi sur l'environnement Nouvelle-Écosse devrait prévoir la réalisation de ce genre de relevés.

Traduit par la rédaction 


\section{INTRODUCTION}

In late 1984, Environment Canada approached the Geophysics Division of the former Nova Scotia Research Foundation Corporation (NSRFC) to investigate the use of geophysical methods for the detection of shallow sulphide mineralization in metasedimentary rocks of the Halifax Formation close to the Halifax International Airport (Fig. 1). The "shallowness" of the mineralization specifically referred to construction depths (i.e., within a few metres of the surface) as it was known that exposure and subsequent oxidation of sulphide minerals in the Halifax Formation causes acid rock drainage (ARD).

Reconnaissance geophysical test measurements were carried out over two grids (Fig. 1) in January, 1985 (NSRFC, 1985a). During April and May, 1985, test pits were excavated and bedrock samples collected at selected geophysical anomalies on both grids (NSRFC, 1985b). In 1985, these unpublished reports documented one of the first, if not the first, environmental geophysical investigations of this type in Nova Scotia. The purpose of this paper is to publicize the results of this reconnaissance study, and to show that geophysical studies may be useful components of environmental assessments for ARD.

\section{ACID ROCK DRAINAGE IN METASEDIMENTARY ROCKS of the Meguma Group}

The Meguma Group (Fig. 1) consists of greywacke and minor interbedded green to grey slate of the Cambrian-Early Ordovician Goldenville Formation and black slate and minor greywacke of the Early Ordovician Halifax Formation. The Halifax Formation is known to contain substantial amounts (up to $10 \%$ by volume) of sulphide minerals. The major sulphide minerals are pyrrhotite and pyrite, with lesser amounts of chalcopyrite and arsenopyrite (McGrath, 1970; Schwarz and McGrath, 1974; Schwarz and Broome, 1994; King, 1997; Fox et al., 1997). The Goldenville Formation is also known to contain sulphide minerals (e.g., pyrite, pyrrhotite, and arsenopyrite) in thin slate beds in areas of gold occurrences (Sangster, 1990). However, the reconnaissance geophysical test grids of this study are wholly situated on the Halifax Formation (Fig. 1).

For more than thirty years, ARD due to the oxidation of sulphide minerals in rocks of the Halifax Formation has been recognized in various parts of Nova Scotia (Pettipas, 1979; Hennigar and Gibb, 1987; Lund et al., 1987; King and Hart, 1990; Pasava et al., 1995). ARD, characterized by low pH (2-4) and high dissolved metal content, arises from the exposure of the Halifax Formation due to construction activities such as highways. The most publicized example of ARD in Nova Scotia resulted from construction of the Halifax International Airport (Fig. 1), which commenced in the mid 1950's. Major amelioration efforts have been ongoing at the airport from at least 1982 to the present (Worgan, 1987; S. Hicks, personal communication, 1998).

As a result of the ARD problem, the Nova Scotia Department of the Environment (NSDOE), in association with Envi- ronment Canada, wrote "Guidelines for Development on Slates in Nova Scotia" in 1985. These guidelines were subsequently revised in 1991. Recently, NSDOE has passed the "SulphideBearing Material Disposal Regulations" of the Environment Act (Environment Act, 1994-95, c.1, s.1). These regulations require that $A R D$ predictive chemical tests be carried out prior to construction activities which will expose the rocks to oxidizing conditions. Examples of these tests include the British Columbia Research Initial Test (Bruynesteyn and Duncan, 1979) and the EPA-600 acid base accounting procedure (Sobek et al., 1978). However, these chemical tests are only useful if the rock can be sampled from outcrop or by drilling and trenching. Non-destructive tests for the detection of sulphide minerals using geophysical methods are not included in the regulations.

\section{Physical Properties of SUlphide minerals IN THE Halifax Formation}

Pyrrhotite has a crystal structure that is deficient in iron, leading to the general formula $\mathrm{Fe}_{1-\mathrm{x}} \mathrm{S}$, where $\mathrm{x}$ can range from 0 to 0.2 . In order to maintain an electrically neutral crystal structure, an ideal formula for pyrrhotite can be written as $\left(\mathrm{Fe}^{2+}{ }_{1-3 x} \mathrm{Fe}^{3+}\right) \mathrm{V}_{\mathrm{x}} \mathrm{S}$, where $\mathrm{V}$ represents vacancies in the cation position (Klein and Hurlbut, 1993). The presence of $\mathrm{Fe}^{3+}$ has been confirmed spectroscopically by Pratt et al. (1994), who found approximately $30 \% \mathrm{Fe}^{3+}$ in pyrrhotite from Mexico.

The iron deficiency and vacancy ordering in the pyrrhotite crystal structure gives the mineral its magnetic properties. One of the most iron-deficient end members is monoclinic pyrrhotite $\left(\mathrm{Fe}_{7} \mathrm{~S}_{8}\right)$, where $\mathrm{x}=0.125$. Hence, monoclinic pyrrhotite is ferrimagnetic whereas the other common hexagonal phases such as $\mathrm{Fe}_{9} \mathrm{~S}_{10}$ and $\mathrm{Fe}_{11} \mathrm{~S}_{12}$ are antiferromagnetic (Dunlop and Ozdemir, 1997). Previous studies (Pasava et al., 1995; Fox et al., 1997) have shown that monoclinic pyrrhotite, with an approximate formula of $\mathrm{Fe}_{7} \mathrm{~S}_{8}$, is present in the Halifax Formation near the Halifax International Airport. Pyrite, in the form of large (1-2 cm) pyrite crystals (or their outlines), also occurs in the slate exposures.

Although pyrrhotite was known to occur in the Halifax Formation in 1985, the prevalent view of personnel in Environment Canada at the time of the geophysical investigation described in this paper was that pyrite oxidation was the main cause of ARD. However, it is now known that pyrrhotite is a major contributor to ARD. The oxidation rate of pyrrhotite can be as much as 100 times faster than that of pyrite (e.g., Nicholson and Scharer, 1994).

Significant total field magnetic anomalies are known to be associated with the Halifax Formation (Geological Survey of Canada Aeromagnetic Series Maps 790G and 785G; 1960), with amplitudes varying between 300 and 600 nanotesla over thick slate units. Magnetic anomalies associated with the Halifax Formation are primarily caused by pyrrhotite. In contrast, as a result of a dam site investigation, Howells and MacKay (1985) noted that the magnetic "fabric" of the Goldenville Formation, as delineated by detailed ground magnetic surveys, consists of small (tens of nanotesla) magnetic anomalies associated with thin slate units within greywacke. Ac- 


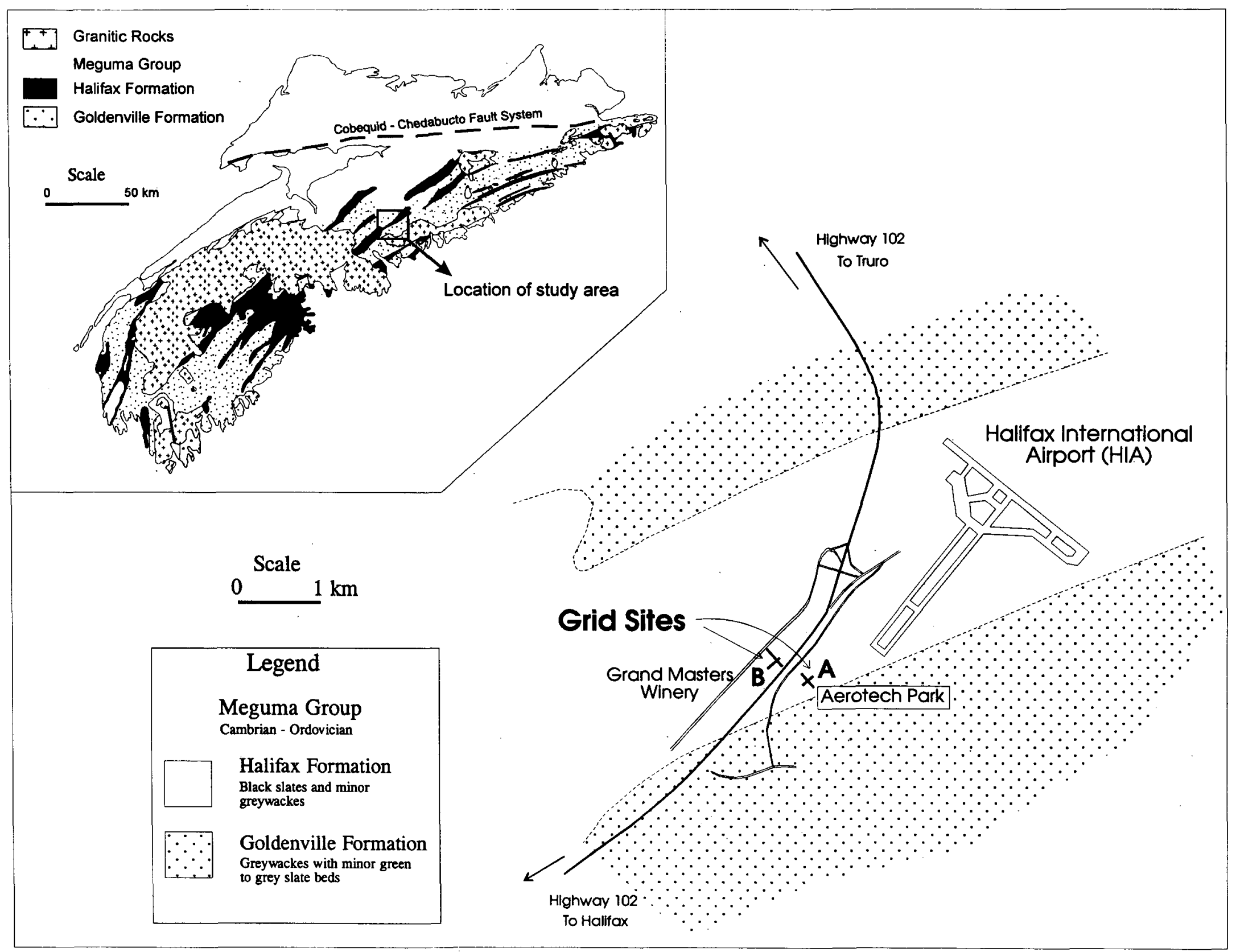

Fig. 1. Simplified geological map and location of geophysical grids near Halifax International Airport. Inset map shows distribution of Meguma Group in Nova Scotia. 
cording to McGrath (1970), magnetic anomalies in the Goldenville Formation result from magnetite. McGrath (1970) also concluded that magnetite is the dominant magnetic mineral in contact metamorphic aureoles surrounding Devonian granites intruded into the Meguma Group.

The magnetic susceptibility ranges of pyrrhotite and magnetite ores are given as $1 \times 10^{3}$ to $1 \times 10^{-1}$ and $7 \times 10^{-2}$ to $14 \mathrm{SI}$, respectively (Parasnis, 1986). In contrast, pyrite ore has a magnetic susceptibility range of only $1 \times 10^{-3}$ to $5 \times 10^{-3} \mathrm{SI}$ units and is relatively non-magnetic. King (1997) reported mean susceptibilities ranging from a minimum of $0.11 \times 10^{-3} \mathrm{SI}$ units (undivided Goldenville Formation) to a maximum of 1.68 $\times 10^{-3} \mathrm{SI}$ units (upper beds, Goldenville-Halifax Transition zone) in central Nova Scotia.

The electrical conductivity of slate varies between $2.5 \mathrm{x}$ $10^{-5}$ and 1.7 millimhos/metre (Telford et al., 1976). In contrast, sulphide minerals are relatively good conductors, with electrical conductivities of pyrite, chalcopyrite, and pyrrhotite having ranges of 102 to 107, 104 to 107, and 106 to 108 millimhos/ metre, respectively. Hence, the presence of sulphides in the Halifax Formation is likely to result in more conductive zones. Graphite, another good conductor (10-102 millimhos/metre; Telford et al., 1976), also occurs in slate of the Halifax Formation and contributes to increased conductivity. However, graphite has a low (negative) magnetic susceptibility. Magnetite, if present, is also quite conductive (102-105 millimhos/metre; Telford et al., 1976) and will increase overall rock conductivity.

These mineral properties indicate that the detection of shallow sulphide mineralization in the Halifax Formation requires geophysical methods capable of measuring conductivity (or resistivity) anomalies, as well as magnetic intensity or susceptibility variations.

\section{GEOPHYSICAL METHODS AND INSTRUMENTATION}

The geophysical methods evaluated, based on anticipated conductivity/resistivity variations, were Continuous Reading Ground Conductivity, Very Low Frequency (VLF) Electromagnetic (EM), and Induced Polarization. A spontaneous polarization survey was done to measure natural or spontaneous potentials in the subsurface associated with weathering of sulphide-rich zones. A magnetic survey was included to provide a comparison with the conductivity (resistivity) measurements and the results of previous ground magnetic surveys over the Meguma Group (e.g., Golder Associates, 1983).

Selection of geophysical equipment was constrained by the availability of local, or in-house, instruments or rental equipment. The ground conductivity instrument used was a Geonics EM31-D non-contacting ground conductivity meter (McNeill, 1980). This horizontal twin loop system has an intercoil spacing of $3.7 \mathrm{~m}$ and an operating frequency of $9.8 \mathrm{kHz}$. Its measurement accuracy is $\pm 5 \%$ at 20 millimhos $/ \mathrm{m}$. It must be emphasised that this instrument was chosen to address the main purpose of the investigation (i.e., the detection of sulphide mineralization within construction depths below the ground surface). The effective exploration depth limit for the
EM31-D is $3 \mathrm{~m}$ when operated in the horizontal dipole configuration and $6 \mathrm{~m}$ in the vertical dipole configuration.

A Geonics VLF EM16 instrument was used for the Very Low Frequency (VLF) Electromagnetic (EM) survey. This receiver measures in-phase and out-of-phase (quadrature) components as percentages of the primary field and utilizes 16-24 $\mathrm{kHz}$ signals broadcast by marine and air navigation systems. VLF EM surveys are an integral part of most mineral exploration programs and are particularly useful for delineating conductive fault and shear zones. The effective exploration depth is several tens of metres.

Induced polarization (IP) effects were measured with a McPhar Dual Frequency System. This equipment measures both apparent resistivity (ohm-metres) and the induced polarization effect or "metal factor" (in mhos/m). Disseminated sulphides with as little as $0.5 \%$ by volume have been successfully identified as being the cause of IP anomalies.

The spontaneous potential equipment consists of nonpolarizing electrodes and a high impedance digital millivoltmeter. The non-polarizing electrodes are porous pots filled with copper sulphate solution. The high-input impedance (more than 108 ohms) digital voltmeter was necessary so that negligible current was drawn from the ground during the measurements.

The total field magnetic measurements were made with a Scintrex MP-2 digital proton precession magnetometer which has a reading accuracy of \pm 1 nanotesla over its operating range.

\section{TEST SITES AND GEOPHYSICAL SURVEY METHODS}

The two test sites (Figs. 1, 2, 3) were selected by Environment Canada personnel so as to sample different parts of the Halifax Formation in the vicinity of Halifax International Airport. Site A (Fig. 2), is located in the Aerotech Park, to the east of Highway 102, and had already been cleared and lay close to an area of previous geotechnical investigations. Site B (Fig. 3), which is situated near the former Grand Masters Winery building, to the west of Highway 102, had previously cut lines within its boundaries.

On both sites, Environment Canada personnel chained and staked two perpendicular lines of suitable length along the cut lines. All ground measurements were in feet with station intervals at 25 foot $(7.62 \mathrm{~m})$ spacing. Both test sites are located on relatively flat ground. The staked lines on each test site were configured so as to be, very approximately, either parallel or perpendicular to the strike of bedding in the Halifax Formation.

Due to time and weather limitations, and the reconnaissance nature of the geophysical surveys, the ground conductivity measurements were carried out at waist height in the vertical dipole configuration (6 $\mathrm{m}$ effective penetration depth) at each station. Hence, conductivity layering beneath the surface was not measured. The VLF EM survey consisted of in-phase and out-of-phase (quadrature) measurements at each station.

The induced polarization equipment was employed in the dipole-dipole electrode configuration using steel electrodes. 


\section{Grid Site A - Aerotech Park}

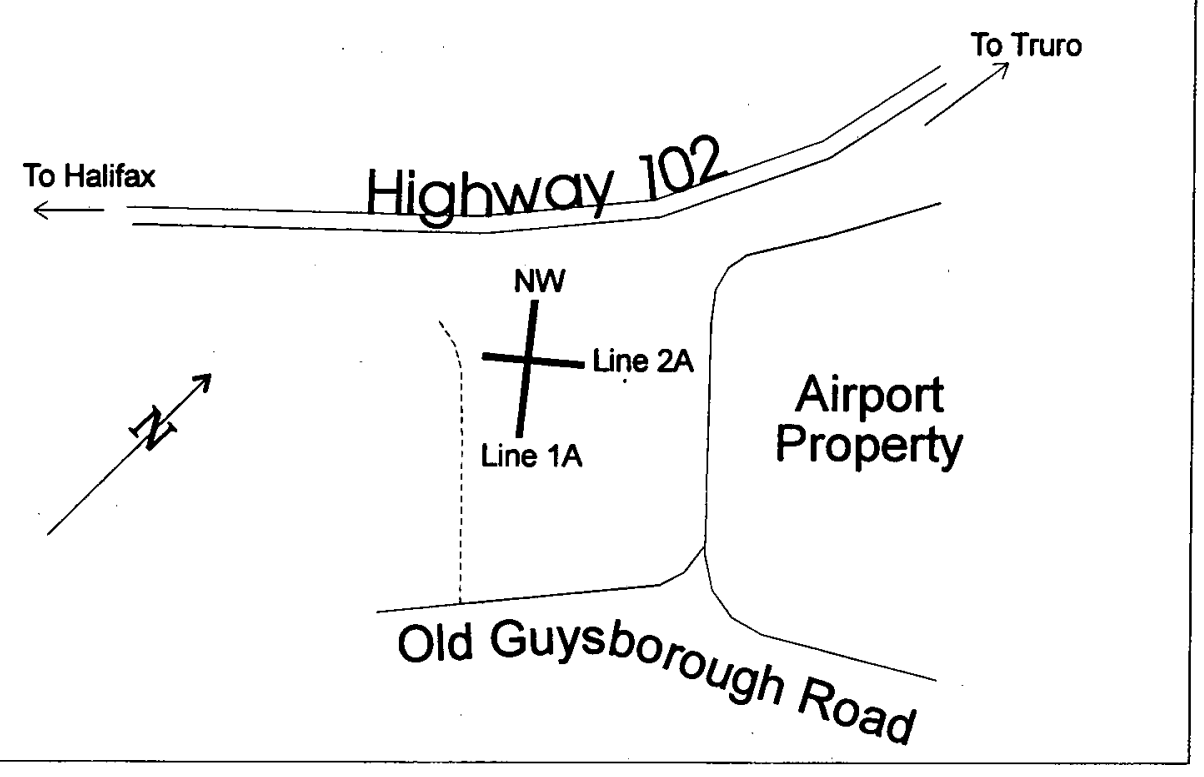

Key:

Qv = anomalies detected by:

magnetometer (m);

conductivity meter (c);

VLF EM (v)

$\mathbf{O}=$ hole location for

rock samples

US, MS, BS = rock samples taken from top, middle and bottom of

hole respectively

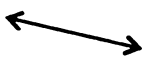

Approximate strike of bedding

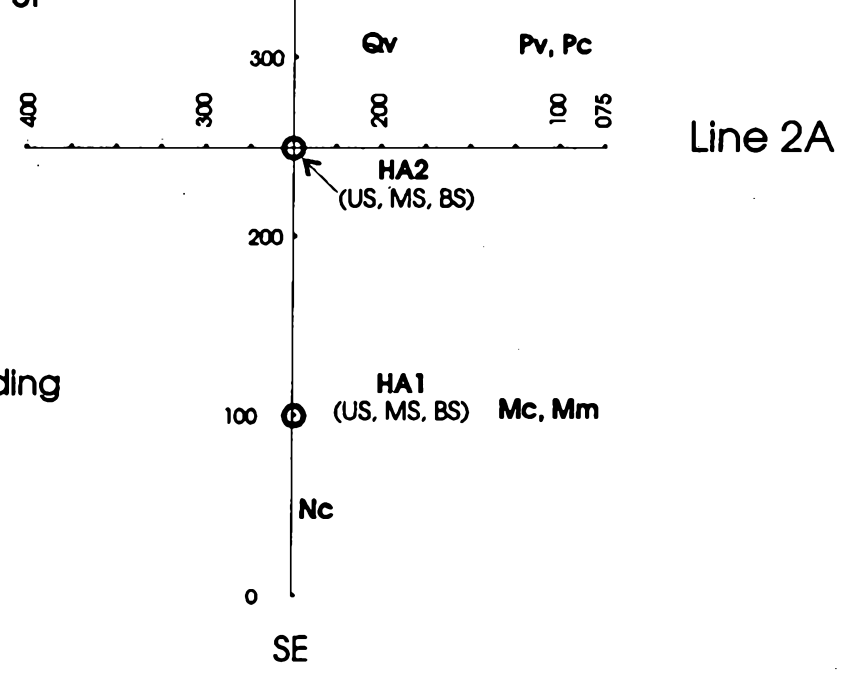

Fig. 2. Detailed map showing location of grid site A (Aerotech Park) with geophysical anomaly and rock sample locations. 


\section{Grid Site B - Grand Masters Winery}

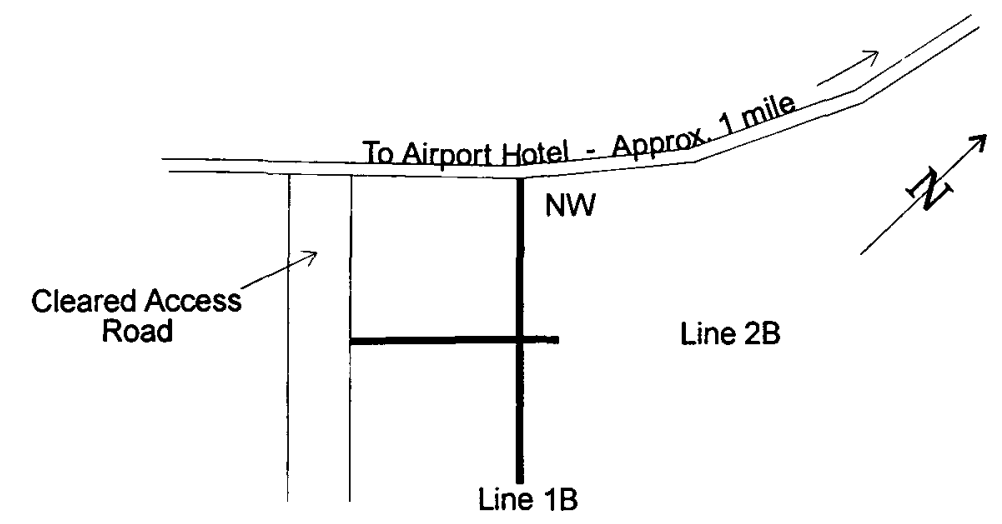

To Halifax

Highway 102

To Truro

Key:

Qv = anomalies detected by

magnetometer $(\mathrm{m})$; conductivity meter (c);

VLF EM (v)

$\mathrm{O}=$ hole location for rock samples

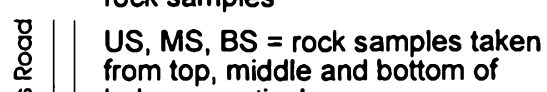
from top, middle and bottom of hole respectively<smiles>[CH]C</smiles>

Approximate strike of bedding

\section{Line 1B}

NW

HBA

(US, MS) Rc, Rm, Rv

600

500

500

400

300

(US, MS, BS) SC

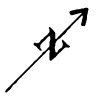

200 HB2

(US) Um, Uv

100

HBI

(US, MS) TV, TC

Fig. 3. Detailed map showing location of grid site B (Grand Masters Winery) with geophysical anomaly and rock sample locations.

Some difficulties were encountered with this method which, at the time, were attributed to high surface resistivities and the winter ground conditions (i.e., frozen ground surface). Therefore, induced polarization measurements were success- fully measured only on line $1 \mathrm{~A}$, at both 12.5 foot $(3.81 \mathrm{~m})$ and 25 foot (7.62 m) dipole intervals.

The porous pots of the spontaneous potential system were buried a few centimetres in the ground and allowed to 
"sit" for a few minutes to obtain a good contact. Expanding spread measurements were acquired by keeping one electrode fixed at a base station while the second electrode was moved to successive locations along the survey line. Spontaneous potential gradients were measured by simultaneously moving both electrodes while maintaining a fixed horizontal distance between them. Expanding spread spontaneous potentials and gradients were successfully measured on line 1A.

Total field magnetic measurements were read at each station and magnetic diurnal variations removed by repeating measurements at base stations at short time intervals. The diurnal magnetic variations were found to be relatively small during the survey.

\section{GeOLOGY OF THE TEST SITE AREAS}

The geological map of the area (Faribault, 1909) shows that both test sites are located on the Halifax Formation in a synclinal structure with steeply dipping or vertical beds close to the syncline axis. The whole area is covered with a clayeysilt to silty-clay glacial till, thickness of which varies from very thin to more than $4 \mathrm{~m}$.

Detailed geotechnical and other investigations were carried out within site A (Fig. 2) by Nolan, Davis and Associates (1983), Golder Associates (1983) and Jacques, Whitford and Associates (1981). These studies reported near vertical slate beds, with strike varying between $240^{\circ}$ and $253^{\circ}$. A thin till, ranging from 0 to $3.42 \mathrm{~m}$ in thickness, overlies the bedrock. However, its average thickness is less than $2 \mathrm{~m}$. While carrying out magnetometer measurements, Golder Associates (1983) reported that "bedrock is exposed at the ground surface more frequently than was initially envisaged". A thin $(0-0.53 \mathrm{~m})$ soil overlies both till and bedrock. Samples from test pits at site A show that pyrite is randomly distributed in the rocks both along strike and with depth (Nolan, Davis and Associates, 1983).

Prior to the geophysical tests described in this paper, little or no detailed geological information was available for site B (Fig. 3). Extensive peat-like deposits were found to occur to the southwest of site B during land-clearing operations.

\section{GEOPHYSICAL SURVEY RESULTS}

\section{Site A, line 1A}

Line 1A trends northwest-southeast, approximately perpendicular to bedding in the slate (Fig. 2). A relatively large ( $38 \mathrm{mmhos} / \mathrm{m}$ ) conductivity anomaly (Mc on Fig. 4) occurs at approximately 100 feet $(30.48 \mathrm{~m})$ along the line, with a subsidiary anomaly (Nc; $26 \mathrm{mmhos} / \mathrm{m})$ at 50 feet $(15.24 \mathrm{~m})$ south of Mc. The steep gradients indicate a shallow source for the conductivity anomaly. A coincident dipole anomaly (Mm on Fig. 4) occurs on the magnetometer profile which may be interpreted to be caused by a prismatic body centred close to 125 feet $(38.10 \mathrm{~m})$.

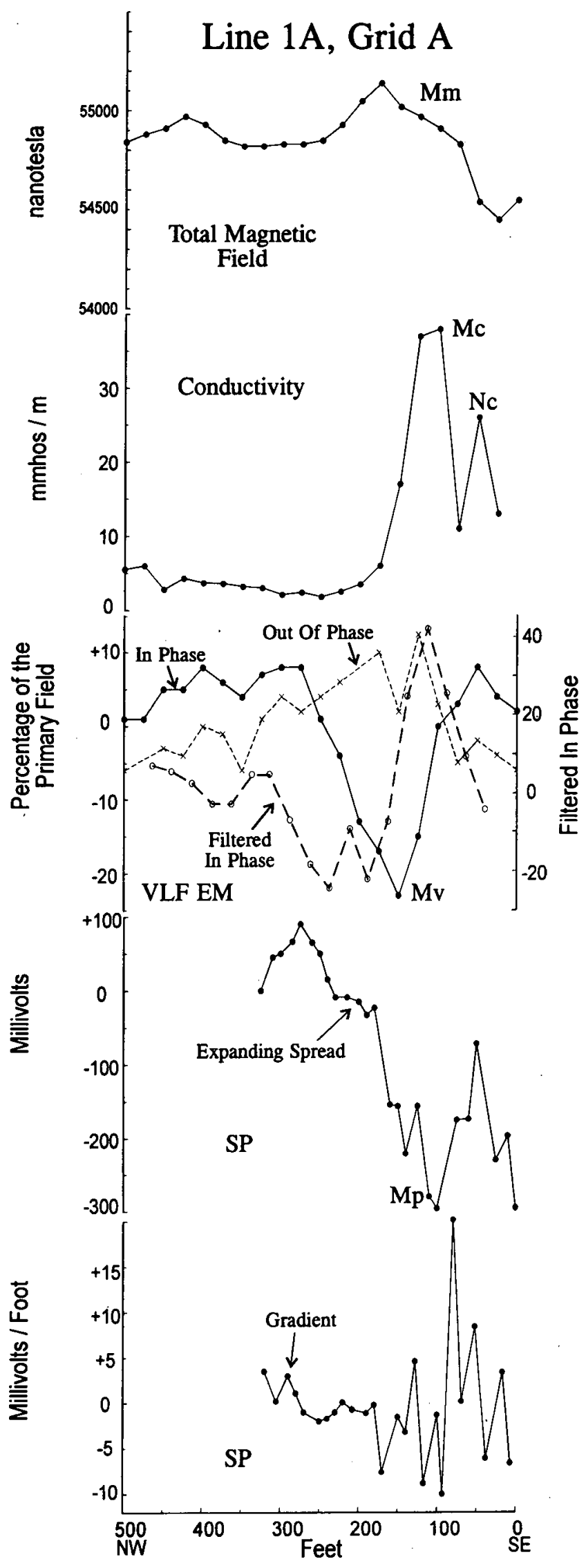

Fig. 4. Magnetic, conductivity, VLF EM and SP profiles for line $1 \mathrm{~A}$, grid site A. 
An expanding spread spontaneous potential profile delineated a large ( -300 millivolts) anomaly centred at 100 feet (30.48 m), shown as Mp on Figure 4. Large spontaneous potential horizontal gradient fluctuations occur close to this location. We conclude that the causative body is both magnetic and conductive. Mineralized bodies frequently produce negative spontaneous potentials at their upper surfaces (Telford et al., 1976).

The VLF EM measurements show a coincident in-phase negative anomaly between 260 and 100 feet (79.25 and 30.48 $\mathrm{m}$ ) indicative of a conductive body (Mv on Fig. 4). The inphase profile has been filtered using a method described by Fraser (1969). The filter converts "crossovers" to positive anomalies and reverse "crossovers" to negative values while, at the same time, smoothing the data. The resulting filtered in-phase profile also gives a large positive anomaly at 112.5 feet $(34.3 \mathrm{~m})$ which coincides with the conductivity anomaly, Mc.

Induced polarization measurements were carried out over that part of line $1 \mathrm{~A}$ where magnetic or conductivity anomalies were not detected (approximately 225 to 285 feet or 68.58 to $86.87 \mathrm{~m}$ ). A similar pattern occurs for both dipole spacings (12.5 and 25 feet or 3.81 and $7.62 \mathrm{~m}$.). The relatively large, near-surface apparent resistivities decrease rapidly with depth together with a near-surface, relatively small, apparent induced polarization effect which increases slightly with depth.

\section{Site A, line 2A}

Line 2A is almost parallel to the strike of bedding (Fig. 2). As a result, not surprisingly, the magnetic profile shows low gradients and a relatively small increase (about 100 nanotesla), indicative of low susceptibility contrasts and/or causative bodies at depth (Fig. 5). The conductivity profile reveals an anomaly, approximately $5 \mathrm{mmhos} / \mathrm{m}$ in amplitude, centred at 100 feet $(30.48 \mathrm{~m})$. This anomaly is labelled Pc on Figure 5.

The VLF EM profile suggests the presence of a conductor at about 212 feet $(64.62 \mathrm{~m})$ labelled as $\mathrm{Qv}$ on Figure 5 . Filtering of the in-phase profile suggests that the conductor is at 162.5 feet $(49.5 \mathrm{~m})$.

\section{Site B, line 1B}

Line IB is approximately perpendicular to the strike of bedding (Fig. 3). Three prominent magnetic anomalies are seen (Fig. 6). The largest, $\mathrm{Rm}$, is a positive anomaly approximately 2400 nanotesla in amplitude with steep gradients, suggesting a relatively shallow source. Anomaly $\mathrm{Sm}$ is of smaller amplitude (about +700 nanotesla) with less steep gradients. Anomaly Um is about +1000 nanotesla with gradients of intermediate slope. These three magnetic anomalies are sufficiently close that they interfere with each other.

On the conductivity profile (Fig. 6), a $7 \mathrm{mmhos} / \mathrm{m}$ conductivity anomaly, $R c$, is coincident with the magnetic anomaly $\mathrm{Rm}$. Though appearing to be offset horizontally by a short distance, the $5 \mathrm{mmhos} / \mathrm{m}$ conductivity anomaly, Sc, is sufficiently wide to be correlated with the magnetic anomaly Sm. However, the magnetic anomaly Um appears to have no corresponding conductivity anomaly, whereas the conductivity
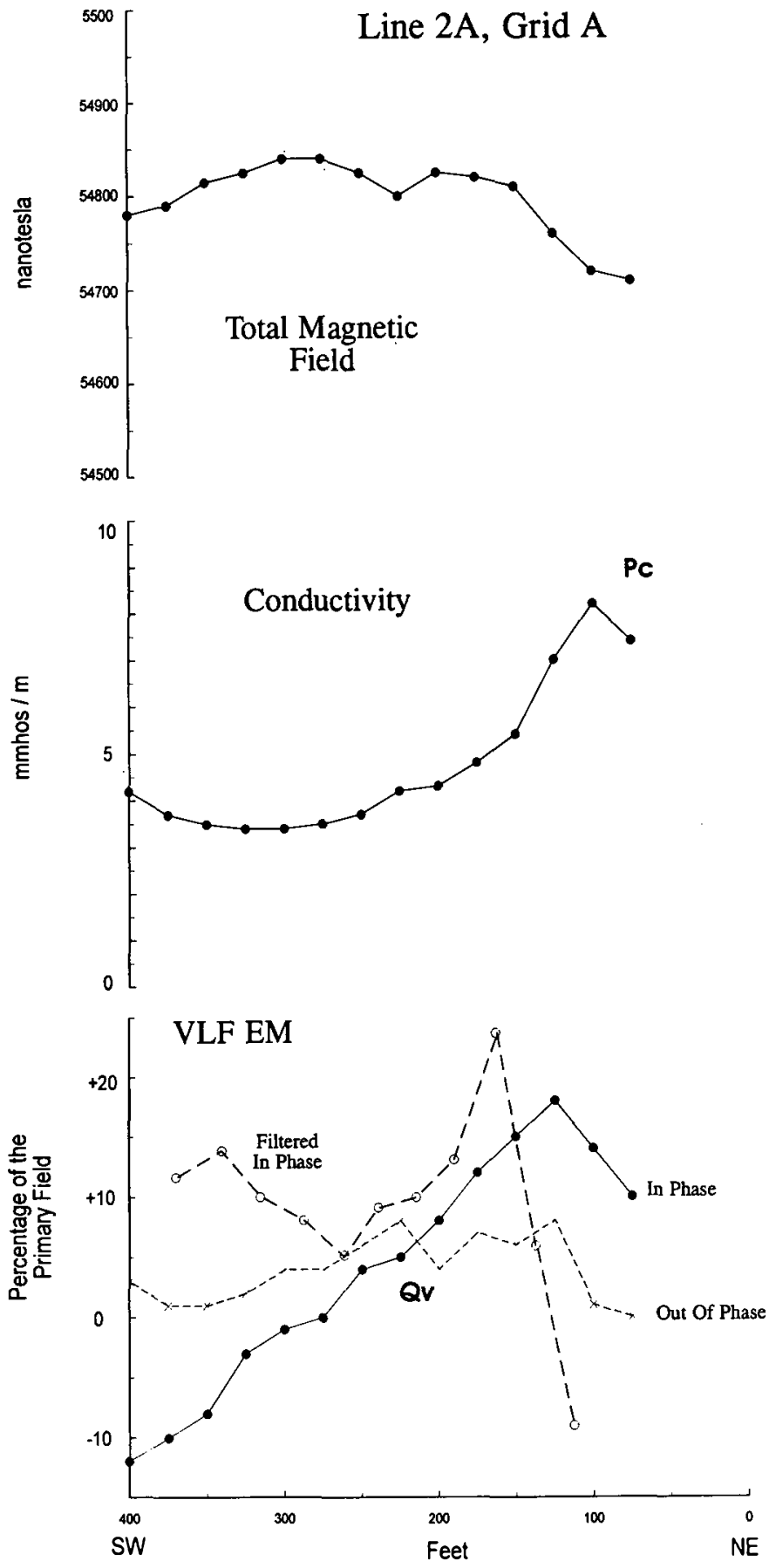

Fig. 5. Magnetic, conductivity and VLF EM profiles for line 2A, grid site A.

anomaly, Tc, at the southeastern end of line 1B, has no corresponding magnetic anomaly.

The VLF EM profile (Fig. 6) has detected in-phase/outof-phase conductor crossovers and anomalies corresponding to all the conductivity and magnetic anomalies (labelled Rv, Sv, Uv and Tv in Fig. 6). The filtered in-phase profile confirms this interpretation.

\section{Site B, line 2B}

Line 2B is approximately parallel to the strike of bedding (Fig. 3). As expected in this situation, the magnetic profile (Fig. 7) is relatively featureless with the exception of the di- 


\section{Line 1B, Grid B}
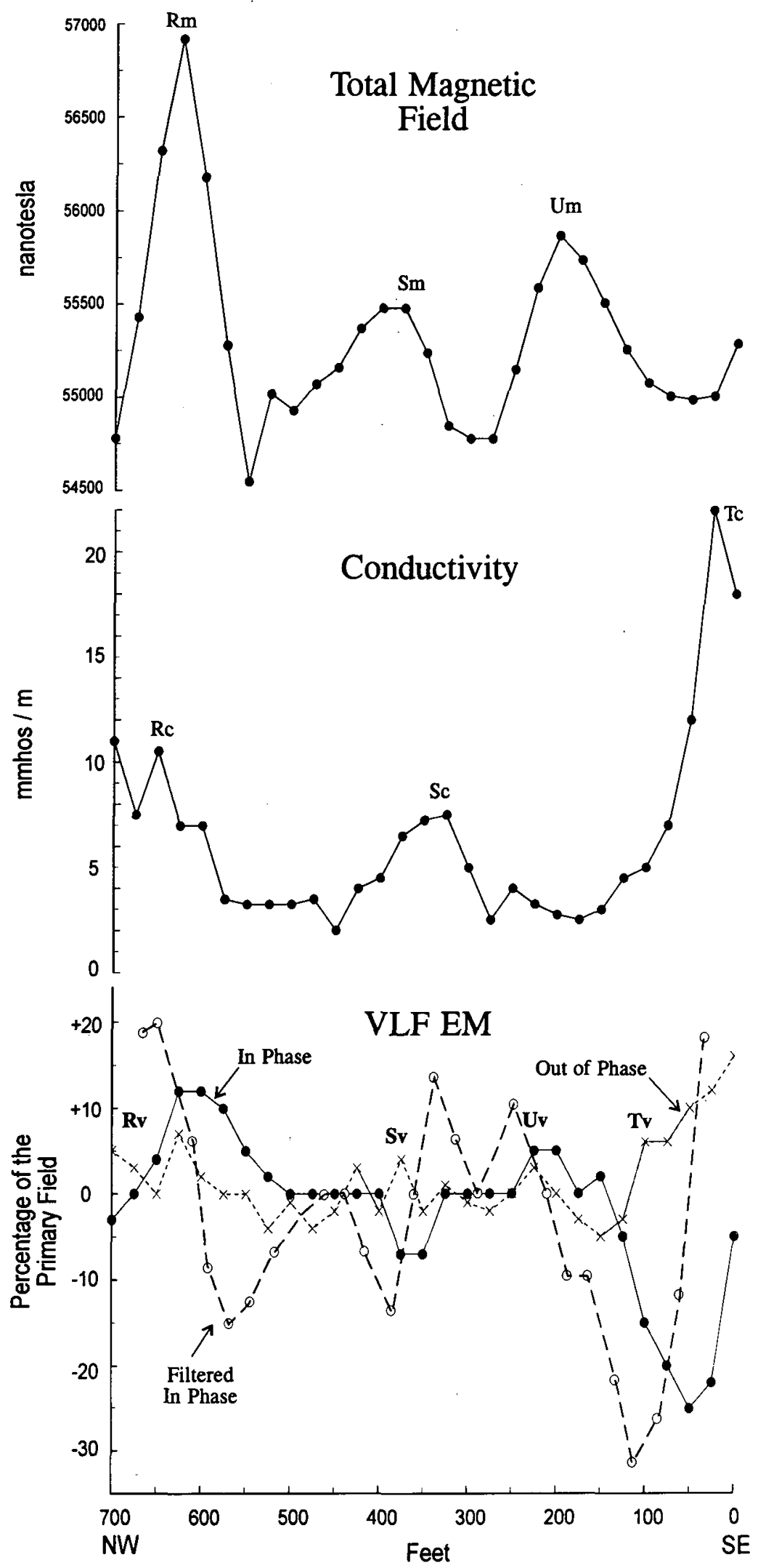

Fig. 6. Magnetic, conductivity and VLF EM profiles for line 1B, grid site B. 


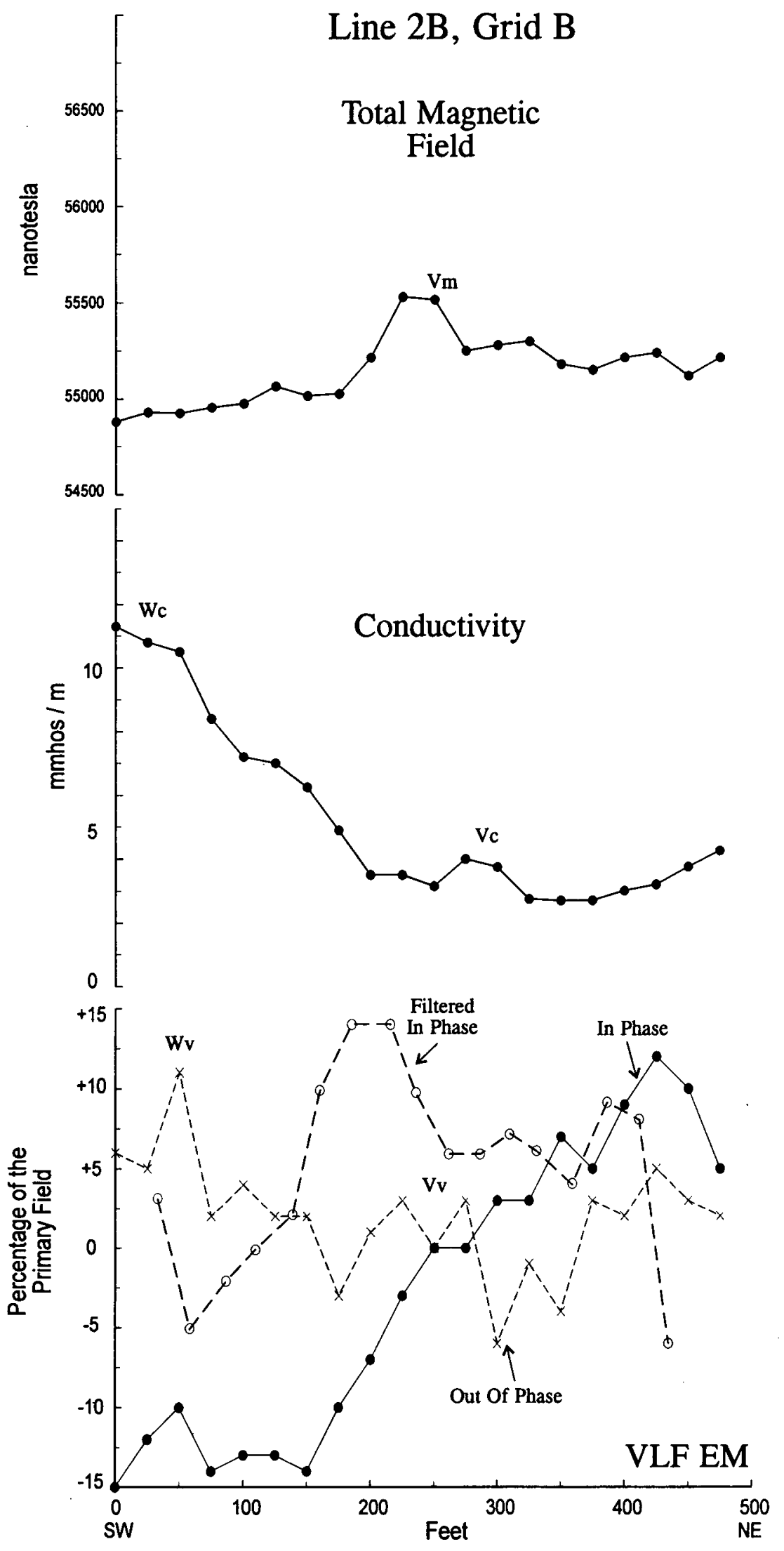

Fig. 7. Magnetic, conductivity and VLF EM profiles for line 2B, grid site B. 
pole anomaly, $\mathrm{Vm}$, the positive part of which is centred at 237 feet (72.24 m) and has an amplitude of only 400 nanotesla. This anomaly is superimposed on a small increase in the total magnetic field from southwest to northeast.

The conductivity profile (Fig. 7) displays a very small (1 $\mathrm{mmho} / \mathrm{m}$ ) conductivity anomaly, Vc, offset by about 55 feet $(16.6 \mathrm{~m})$ to the northeast of the peak of Vm. From 200 feet $(60.96 \mathrm{~m})$ to the southwest end of the profile, conductivity increases by about $8 \mathrm{mmhos} / \mathrm{m}$ with the maximum at 0 feet (Wc). There is no corresponding magnetic anomaly.

The VLF EM profile (Fig. 7) displays a significant inphase/out-of-phase crossover at approximately 250 feet, labelled $\mathrm{Vv}$, to show its correspondence to the related magnetic and conductivity anomalies, Vm and Vc. Small in-phase and out-of-phase increases, labelled Wv on Figure 7, may be the VLF EM anomaly expression of conductivity anomaly Wc. The filtered in-phase profile shows that its positive peak at 200 feet $(61 \mathrm{~m})$ is likely due to the same causative body as for $\mathrm{Vm}$ and Vc. Part of a filtered in phase positive anomaly is located close to Wv and Wc but is at the southwest limit of the data.

\section{BEDROCK SAMPLING ON THE TEST GRIDS}

Bedrock sampling was carried out, based on the results of the previously described geophysical measurements. The purpose of the sampling was to measure sulphide mineralization variation and to correlate the results with observed geophysical anomalies. This phase of the investigation carried out in April, 1985, used a backhoe to excavate rock samples at the locations shown in Figure 2 (HAl and HA2) and Figure 3 (HB1 to HB4) which correspond to selected geophysical anomalies on lines $1 A$ and $1 B$.

Bedrock depths and overburden thickness varied over both lines (Fig. 8). At HB2, the bedrock surface was close to the $3 \mathrm{~m}$ excavation limit of the backhoe. At each excavation, rock samples were obtained from bedrock. The intent was to obtain rock samples at different depths in each pit but this was not possible in pits $\mathrm{HB} 1$ and HB2 due to large overburden thicknesses (Fig. 8). As a result of the variation in overburden thickness, rocks were sampled at widely varying depths below the ground surface in each pit.

\section{Chemical analyses of Bedrock SAMPLES}

Environment Canada personnel specified the chemical analyses to be done on each rock sample. The analyses included total sulphur, pyritic sulphur, non-pyritic sulphide, magnetite and graphite content (all in weight \%). The total sulphur content was measured using a Leco Automatic Sulphur Analyser. Pyritic sulphur content was determined using the ASTM D 2492 method which is the standard test for forms of sulphur in coal (American Society for Testing and Materials, 1990). In this method, iron is measured from a dilute nitric acid extraction performed on the residue remaining after the sulphate extraction with dilute hydrochloric acid. The pyritic sulphur is calculated from the iron analysis assuming ideal $\mathrm{FeS}_{2}$ and a stoichiometric ratio of sulphur to iron equal to
1.148. The non-pyritic sulphide content was determined by measuring acid evolution by back titration. Magnetite content was calculated from $\mathrm{Fe}^{3+}$ content, determined by wet chemical methods. Graphite content was determined by measuring the amount of carbon insoluble in hydrochloric acid. Total acid potential, in units of tonnes $\mathrm{CaCO}_{3} / 1000$ tonnes, is calculated by multiplying the total sulphur content by 31.25 (Price, 1997). The assumption made in this calculation is that all of the sulphur occurs in the form of pyrite and that the pyrite reacts by the following equation:

$$
\begin{array}{r}
\mathrm{FeS}_{2}+2 \mathrm{CaCO}_{3}+3.75 \mathrm{O}_{2}+1.5 \mathrm{H}_{2} \mathrm{O} \longrightarrow \mathrm{Fe}(\mathrm{OH})_{3}+2 \mathrm{SO}_{4}{ }^{2-}+ \\
2 \mathrm{Ca}^{2+}+2 \mathrm{CO}_{2}
\end{array}
$$

In the report by NSRFC (1985b), the total acid potential values were presented as "acid producing potential" and given in units of $\mathrm{lbs} /$ ton. Table 1 gives the results of the chemical analyses and the total acid potential, calculated in units of tonnes $\mathrm{CaCO}_{3} / 1000$ tonnes. The amounts of non-pyritic sulphides measured were insufficient to determine the identity and amount of individual non-pyritic sulphides as had been anticipated prior to the analyses (NSRFC, 1985b).

The term "pyritic sulphur" is a simplification as, in the coal industry, it is usually not necessary to differentiate between and identify individual sulphide minerals. According to the test specifications, this procedure is a measure of the iron content after a nitric acid leach. It includes the iron content from other iron-bearing minerals in the rock samples. As previously described, considerable amounts of pyrrhotite and other sulphide minerals occur in the Halifax Formation (Fox et al., 1997). Iron is also a constituent of minerals such as biotite, chlorite, ilmenite, garnet, and some carbonates, all of which occur in the Halifax Formation (Hingston, 1985; MacInnis, 1986; Feetham et al., 1997). Hence, "pyritic sulphur" is a misnomer and a more appropriate term is "nitric acid leachable iron". For similar reasons, the "non-pyritic sulphide" values are inappropriate in that the terminology is not sufficiently specific to determine exactly what the "non-pyritic" content represents.

Similarly, to calculate "total weight \% magnetite content" using the $\mathrm{Fe}^{3+}$ values is probably incorrect again due to the substantial amounts of pyrrhotite and other iron-bearing minerals in the Halifax Formation including chlorite, biotite, garnet, ilmenite and carbonate, all of which can contain $\mathrm{Fe}^{3+}$.

The total weight \% "graphitic carbon" in Table 1 refers only to the weight \% "non-carbonate carbon" present in the rock samples, as other forms of carbonaceous material in addition to graphite are known to occur in the Halifax Formation (MacInnis, 1986).

\section{RESISTIVITY MEASUREMENTS OF BEDROCK SAMPLES}

The electrical resistivities of some test site rock samples were measured using both tinfoil and copper electrodes. The rock samples were cut into rectangular blocks with length at least four times greater than width and height. Each specimen was water saturated for 12,16 and 48 hours in water obtained 
NW - SE Line 1A- Grid Site A

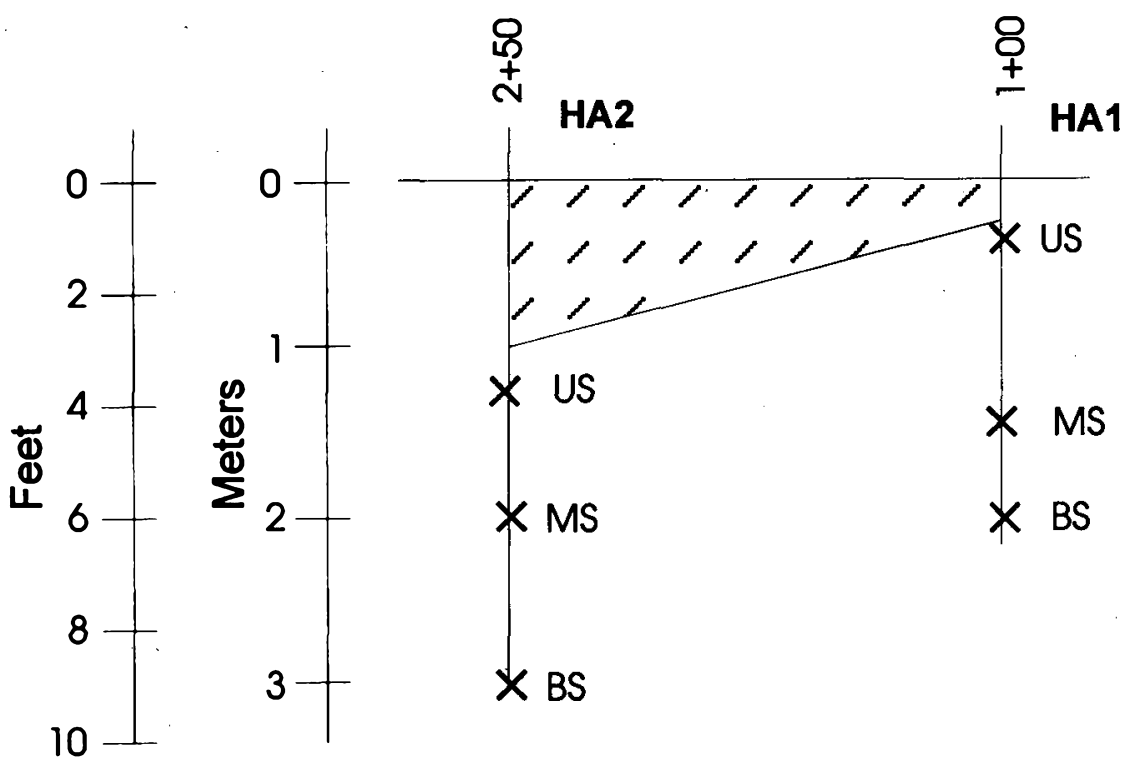

\section{NW - SE Line 1B- Grid Site B}

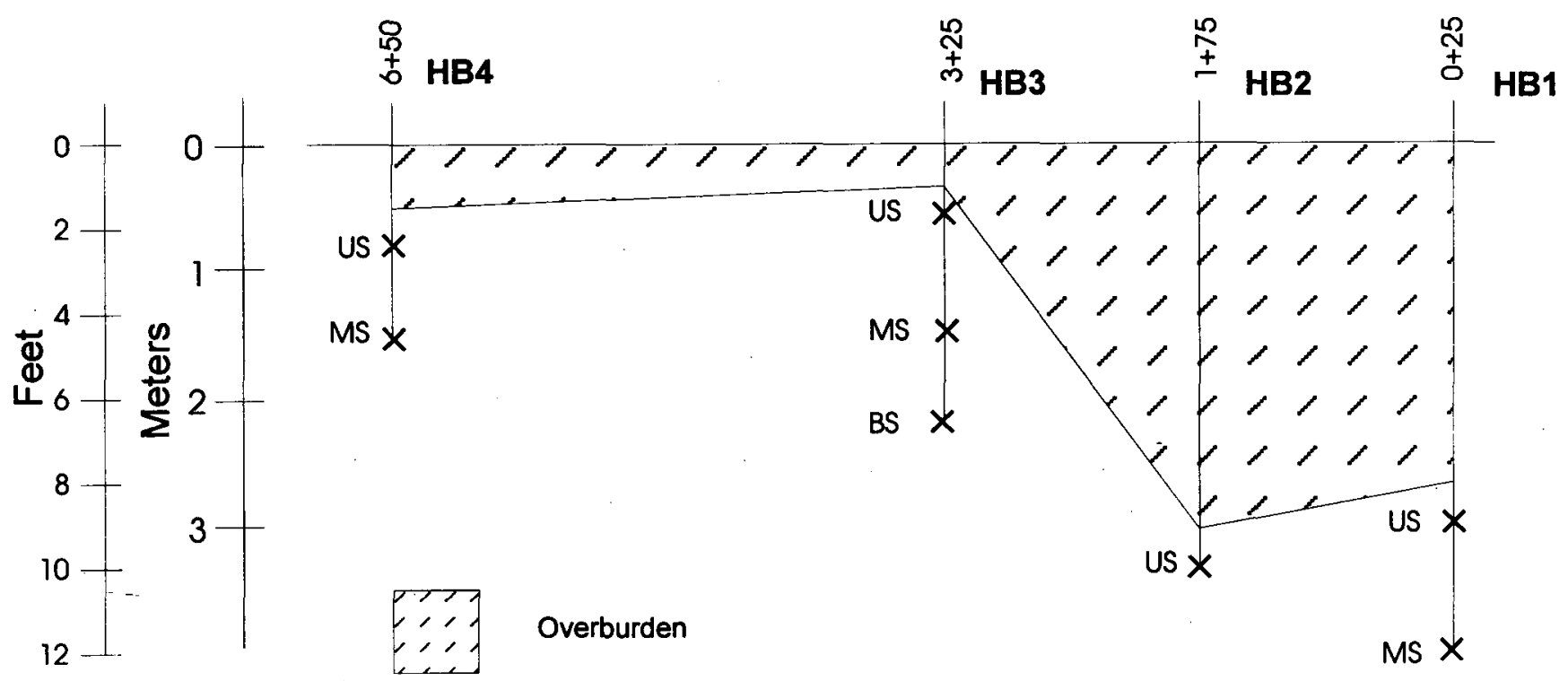

Bedrock

US, MS, BS Rock Sample - Upper, Middle, Bottom

Fig. 8. Overburden thicknesses, test pit and rock sample locations for lines $1 \mathrm{~A}$ (grid site A) and $1 \mathrm{~B}$ (grid site B).

from the grid sites. Saturation was achieved by placing the sample in a container of groundwater at room temperature and pressure and, in addition, at room temperature and in vacuo (for 12 hours).

Rock conductivities measured using the tinfoil electrodes have higher values at $\mathrm{HAl}(1.5-7.7 \mathrm{mmhos} / \mathrm{m})$ compared to HA2 (0.23-1.0 mmhos/m) on grid A (Fig. 8). The measured increase confirms the increase as measured by the ground conductivity meter (Fig. 4: Mc and Nc). The difference in amplitude between the laboratory and field conductivity values may be explained by the survey measurements being the result of the contribution from the entire conductive zone whereas the laboratory measurements are for individual rock specimens. Conductivity values for HB1, HB3 and HB4 on grid B (Fig. 8) are 0.5 to $2.3 ; 0.04$ to 3.6 ; and 0.2 to $2.3 \mathrm{mmhos} /$ $\mathrm{m}$ respectively. Each of these holes sampled locations at which 
Table 1. Chemical analyses of rock samples.

\begin{tabular}{|c|c|c|c|c|c|c|c|c|}
\hline $\begin{array}{l}\text { Lab } \\
\text { Number }\end{array}$ & $\begin{array}{l}\text { Grid Sample } \\
\text { Location }\end{array}$ & Description & $\begin{array}{c}\text { wt. \% } \\
\text { Total Sulphur }\end{array}$ & $\begin{array}{c}\text { Total Acid Potential } \\
\text { (tonnes } \mathrm{CaCO}_{3} \text { ) } \\
\text { (per } 1000 \text { tonnes) }\end{array}$ & $\begin{array}{c}\text { wt. \% } \\
\text { Pyritic Sulphur }\end{array}$ & $\begin{array}{c}\text { wt. \% } \\
\text { Non Pyritic } \\
\text { Sulphides }\end{array}$ & $\begin{array}{c}\text { wt. \% } \\
\text { Graphitic Carbon }\end{array}$ & $\begin{array}{l}\text { wt. } \% \\
\text { Fe2t }\end{array}$ \\
\hline \multicolumn{9}{|c|}{ Line $1 \mathrm{~A}$ - Grid A } \\
\hline 1 & 250 (HA2) & Top & 0.034 & 1.06 & 0.030 & $<0.0005$ & 0.18 & 1.98 \\
\hline 2 & & Middle & 0.170 & 5.31 & 0.030 & 0.0028 & 0.92 & 1.55 \\
\hline 3 & & Bottom & 0.070 & 2.19 & 0.013 & $<0.0005$ & 1.36 & 0.76 \\
\hline 15 & 100 (HA1) & Top 1 & 2.000 & 62.50 & 1.860 & 0.0052 & 0.28 & 4.15 \\
\hline 4 & & Top 2 & 0.850 & 26.56 & 0.690 & 0.0048 & 0.25 & 2.69 \\
\hline 5 & & Middle & 2.050 & 64.06 & 1.800 & $<0.0005$ & 1.27 & 1.40 \\
\hline 6 & & Bottom & 1.110 & 34.69 & 0.470 & 0.4260 & 0.60 & 2.45 \\
\hline \multicolumn{9}{|c|}{ Line $1 \mathrm{~B}$ - Grid B } \\
\hline 12 & 650 (HB4) & Top & 1.000 & 31.25 & 0.500 & 0.0149 & 0.39 & 3.12 \\
\hline 13 & & Middle & 2.170 & 67.81 & 1.920 & 0.0308 & 0.18 & 5.82 \\
\hline 9 & 325 (HB3) & Top & 0.060 & 1.88 & 0.020 & 0.0012 & 0.42 & 4.06 \\
\hline 10 & & Middle & 2.190 & 68.44 & 1.660 & 0.0010 & 0.64 & 2.60 \\
\hline 11 & & Bottom & 2.790 & 87.19 & 1.690 & 0.0174 & 0.67 & 1.82 \\
\hline 14 & 175 (HB2) & Top & 0.230 & 7.19 & 0.130 & 0.0237 & 0.12 & 3.19 \\
\hline 7 & 025 (HB1) & Top 1 & $0: 570$ & 17.81 & 0.430 & $<0.0005$ & 1.11 & 2.70 \\
\hline 16 & & Top 2 & 1.860 & 58.13 & 1.660 & 0.0040 & 0.30 & 2.96 \\
\hline 8 & & Middle & 1.600 & 50.00 & 0.800 & 0.2865 & 0.53 & 4.70 \\
\hline
\end{tabular}

elevated survey conductivity values were measured (Fig. 6). The copper electrodes gave higher but inconsistent conductivity values for the rock specimens.

\section{Discussion}

\section{Geophysical measurements}

The magnetic, ground conductivity and VLF EM conductivity anomalies measured on grid sites $A$ and $B$ demonstrate three types of relationships:

\section{(i) Coincident magnetic and conductivity anomalies}

Examples of coincident magnetic, ground conductivity and VLF EM anomalies are Sm, Sc, Sv and Rm, Rc, Rv on line 1B (Fig. 6) and Mm, Mc, Mv on line 1A (Fig. 4). These anomalies, taken together, strongly suggest the presence of conductive and magnetic minerals close to the surface. In fact, the detection limit of the ground conductivity meter requires that the mineralization be within $6 \mathrm{~m}$ of the ground surface. The large conductivity anomaly, Mc, on line 1A (Fig. 4) is coincident with a negative, spontaneous potential anomaly with steep gradients (Mp on Fig. 4) which confirms the presence of a shallow conductor. A crude depth estimate to the top of the conducting body, using the spontaneous potential anomaly, gives a value of $6 \mathrm{~m}$. Simple depth estimates of this type are typically overestimates. Pyrrhotite is both a conductive and magnetic and is the likely cause of these anomalies.

(ii) Conductivity anomalies for which there are no coincident magnetic anomalies

Conductivity anomalies Wc and Wv on line 2B (Fig. 7) and Pc on line 2A (Fig. 5) are examples of ground and VLF EM conductivity anomalies for which there appear to be no corresponding magnetic anomalies. Unfortunately, both examples are toward the end of survey lines and are incomplete anomalies. The conductivity anomalies suggest the presence of nonmagnetic conductors, such as pyrite or graphite.

(iii) Magnetic anomalies for which there are no coincident ground conductivity anomalies

Magnetic anomaly Vm, on line 2B (Fig. 7), has no corresponding ground conductivity anomaly, although there is a small $(1 \mathrm{mmho} / \mathrm{m})$ ground conductivity increase $(\mathrm{Vc})$ about 50 feet $(15 \mathrm{~m})$ to the northeast. However, there is a coincident VLF EM anomaly (in phase/out of phase crossover Vv). Similarly, magnetic anomaly Um (line 1B, Fig. 6) has no corresponding ground conductivity anomaly but has a coincident VLF EM anomaly. The small increase in magnetic values on line 2A (Fig. 5) are centered over the VLF EM crossover at Qv and may also be an example of this relationship. 
One of the conclusions of NSRFC (1985b) was that there was "little, or no, correlation between the magnetic anomalies and the conductivity anomalies". This conclusion was reported by Albright (1987) and was used by Samostie (1994) to state that "previous research indicated little correlation between magnetic anomalies and bedrock mineralization". However, the purpose of the geophysical investigation was to detect shallow sulphide mineralization (i.e., within construction depths of a few metres from the ground surface). The ground conductivity meter, used in the vertical dipole configuration, has an effective penetration depth of $6 \mathrm{~m}$. Hence, in the case of coincident magnetic and VLF EM anomalies with no accompanying ground conductivity anomaly, we are detecting magnetic and conductive bodies which lie below the maximum $6 \mathrm{~m}$ exploration depth of the ground conductivity meter. For instance, simple infinite line pole depth estimates for $\mathrm{Um}$ and $\mathrm{Vm}$ give depths to the causative body of 31 to $43 \mathrm{~m}$ and 15 to $28 \mathrm{~m}$, respectively. These bodies are probably not of significance to any construction activities.

In light of the above, we modify the conclusion of NSRFC (1985b) to suggest that there is some correlation between the magnetic and conductivity anomalies. Any lack of correlation may either be due to the depth of the causative bodies and the maximum exploration depth of the ground conductivity meter (chosen to investigate down to construction depths only) or may be the result of bodies which are conductive but not magnetic.

\section{Correlation of the geophysical anomalies and bedrock sample analyses}

The weight \% total sulphur and carbon have been used for the geophysical and geochemical correlations given the previous discussion on the limitations of the chemical analyses.

On line 1A (Fig. 2), bedrock samples from HAl were collected at three depths (approximately $0.2,1.2$ and $1.8 \mathrm{~m}$ below the ground surface; Fig. 8). Bedrock was covered by a very thin $(0.1 \mathrm{~m})$ overburden layer at this pit. HAl is located at the centre of a ground conductivity anomaly Mc ( $36 \mathrm{mmhos} / \mathrm{m}$ ), and at one of the crossover points of the VLF EM anomaly, Mv (Fig. 4). The filtered in-phase peak also coincides with these anomalies. The rock analyses (Fig. 9) show relatively large amounts of total sulphur and corresponding total acid potential for samples at all three depths. The magnetic dipole anomaly $(\mathrm{Mm})$, the conductivity anomalies (Mc and $\mathrm{Nc}$ ) and the chemical analyses for HAl (Figs. 4, 9) suggest the presence of minerals which are both conductive and magnetic. The most likely candidate is pyrrhotite.

Test pit HA2 was selected to sample an area of extremely low ground conductivity readings (approximately $2 \mathrm{mmhos} /$ m) directly northwest of anomalies Mc, Mv and Mm (Fig. 4). As might be expected, the total sulphur content and, hence, total acid potentials are extremely low (Fig. 9). The samples from this test pit were taken at greater depths (1.1, 1.8 and 2.7 $m$ in Fig. 8) than for HAl due to the increase in overburden thickness ( $0.9 \mathrm{~m}$ in Fig. 8 ).
As a comparison with the field measurements, multi-layer theoretical response calculations (McNeill, 1980) were carried out for the ground conductivity meter in the vertical dipole configuration at a height of $1 \mathrm{~m}$ above the ground surface for line $1 \mathrm{~A}$ at pits $\mathrm{HAl}$ and $\mathrm{HA} 2$. For $\mathrm{HA} 2$, a conductivity of $1 \mathrm{mmho} / \mathrm{m}$ was obtained for the rocks with minor mineralization which lay beneath $1 \mathrm{~m}$ of overburden (with an assumed conductivity of $5.5 \mathrm{mmhos} / \mathrm{m}$ ). For HAl, the model gave a mineralized slate conductivity of $40 \mathrm{mmhos} / \mathrm{m}$ using the same overburden conductivity and an overburden thickness of $0.15 \mathrm{~m}$. These theoretical calculations also gave apparent conductivities at the surface of 2.1 and $37.5 \mathrm{mmhos} / \mathrm{m}$ for the non-mineralized and mineralized slates, respectively.

On line 1B, grid B (Fig. 3) overburden thickness is quite variable, ranging from a minimum of $0.3 \mathrm{~m}$ at $\mathrm{HB} 3$ to a maximum of $2.9 \mathrm{~m}$ at HB2 (Fig. 8). Hence, rock samples were collected at considerably different depths in test pits HBI to HB4. The locations of these test pits were chosen to sample rocks where conductivity and magnetic anomalies were measured (HB1: Tc and Tv; HB2: Um and Uv; HB3: Sm, Sc and Sv; HB4: $\mathrm{Rm}, \mathrm{Rc}$ and $\mathrm{Rv}$ in Figs. 3, 8). For pits HB3 and HB4, where the overburden is thinner and samples taken from shallower depths compared with $\mathrm{HB} 1$ and $\mathrm{HB} 2$, elevated levels of total sulphur and total acid potential were measured (Fig. 9) with the exception of the shallowest $(0.8 \mathrm{~m})$ sample from HB3. This result is in good agreement with the conductivity and magnetic anomalies measured over both pits. The lower gradients of the anomalies at HB3 compared with HB4 may reflect the lack of mineralization in the topmost metre of bedrock at HB3. HB1, coincident with the large ground conductivity anomaly, Tc, also displays elevated total sulphur content (Table 1). However, rock samples from $\mathrm{HB} 2$, where no ground conductivity anomaly occurs, give low total sulphur values (though only the top of the rock surface was sampled due to the deeper overburden at this location).

At $\mathrm{HB} 2$, the $\mathrm{Fe}^{3+}$ content in the bedrock sample can be used to estimate a magnetic susceptibility of approximately $500 \times 10^{-6} \mathrm{cgs}$ units if the $\mathrm{Fe}^{3+}$ content is equated with an assumed magnetite content of $4 \%$ (Heiland, 1963). Assuming that the magnetic anomaly, Um, is caused by a vertically polarized, infinite, horizontal cylinder (Nettleton, 1940) of radius $12.2 \mathrm{~m}$ and depth to centre $15.2 \mathrm{~m}$, and that the earth's magnetic field is 50,000 nanotesla, the calculated magnetic anomaly amplitude is about 100 nanotesla, neglecting remanent magnetization. The magnetic anomaly, Um (Fig. 6), is approximately 1000 nanotesla. Therefore, the major contribution to this magnetic anomaly must be explained by a mineral which is both conductive (VLF EM anomaly Uv, Fig. 6) and magnetic and which attains a significant percentage by weight below the $6 \mathrm{~m}$ effective exploration depth of the ground conductivity meter. We conclude that it is likely that pyrrhotite mineralization is present in significant quantities at a depth of greater than $6 \mathrm{~m}$ in order to explain the large magnetic and VLF EM anomalies at HB2.

We have suggested that the horizontal and vertical distributions of magnetic and conductive sulphides in the Halifax Formation are the cause of the apparent conductivity and 

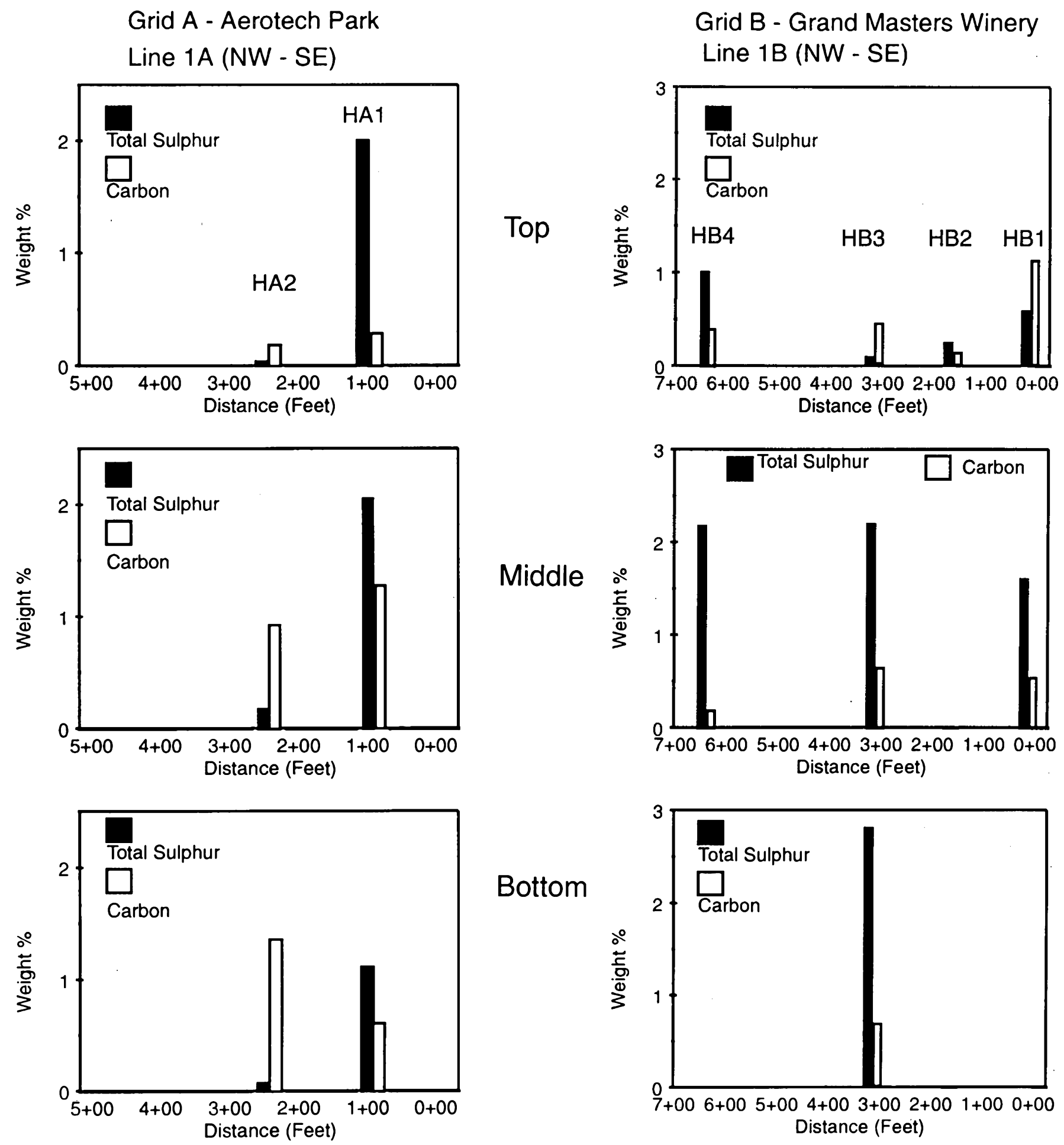

Fig. 9. Bar graphs showing amounts of total sulphur and carbon in rock samples taken from lines $1 \mathrm{~A}$ (grid site A) and $1 \mathrm{~B}$ (grid site B).

magnetic anomalies. However, some conductivity variations may also be due to other factors such as graphite content, changes in bedrock depth (overburden thickness), moisture content, rock and overburden porosity, concentration of dissolved electrolytes in the contained moisture, temperature and phase state of the pore water, amount and composition of colloids and subsurface layer thickness and conductivity contrasts (McNeill, 1980). An example is conductivity anomaly
Wc at the southwest end of line 2B (Fig. 7). This anomaly is shown as a gradual conductivity increase towards the end of the line. An alternative interpretation is that the conductivity increase is the result of increasing overburden conductivity, decreasing overburden thickness or a combination of both effects. Increased graphite content in the bedrock is another possibility. 


\section{Conclusions}

Reconnaissance geophysical surveys on two grids near the Halifax International Airport have suggested that conductivity and magnetic anomalies define zones of sulphide mineralization within construction depths below the surface in the Halifax Formation. This interpretation has been proved by chemical analyses of rock samples excavated from test pits located on selected geophysical anomalies. Increased levels of total sulphur were measured at all test pits where ground conductivity anomalies are present. Two test pits, one on each grid, deliberately chosen to sample areas where no ground conductivity anomaly occurred, gave low contents of total sulphur.

A combination of ground conductivity meter, magnetometer and VLF EM meter is the most effective instrument package to carry out this type of environmentally oriented survey. Readings can be recorded rapidly by one person using automated data recording systems. The effective exploration depth limit of the ground conductivity meter ensures that any ground conductivity anomalies recorded are within construction depths in the surveyed area. Though the spontaneous potential equipment also defined conductivity anomalies, both it and the induced polarization equipment required longer equipment deployment times and additional personnel for effective operation.

Three types of relationships were observed from combinations of ground conductivity, magnetic and VLF EM anomalies. The first consists of coincidental ground conductivity, magnetic and VLF EM anomalies which defines conductive and magnetic mineralization within $6 \mathrm{~m}$ of the ground surface as defined by the ground conductivity meter. We suggest that the main mineral responsible for this combination of anomalies is pyrrhotite, with or without pyrite. The second comprises ground conductivity anomalies with no coincident magnetic anomalies (though VLF EM anomalies may also occur). Pyrite and/or graphite mineralization within $6 \mathrm{~m}$ of the ground surface may cause this combination of anomaly types. The third relationship consists of magnetic and VLF EM anomalies with no coincident ground conductivity anomalies. These anomalies result from magnetic and conductive mineralization, probably pyrrhotite with or without pyrite, at depths greater than $6 \mathrm{~m}$.

As with all remote sensing methods, ground truthing is essential for the interpretation of the geophysical data. Chemical and mineralogical analyses of rock samples obtained from outcrop, test pits, and boreholes ensure the validity of any conclusions drawn from the geophysical interpretation. Geophysical surveys can rapidly define trends, extents, and depths of sulphide-bearing zones in the Halifax Formation in advance of construction projects. Hence, a strong case is made for including these types of geophysical surveys in the Nova Scotia Environment Act.

It is acknowledged that in built up areas, electromagnetic and magnetic surveys may not be practical due to interference from power lines, buildings and other electromagnetic and magnetic sources. Also, the presence of sulphide mineralization does not necessarily indicate that ARD will occur. The overall assessment of ARD must also include such fac- tors as oxidizing conditions, temperature effects, rainfall amounts, and the presence or absence of bacteria.

\section{ACKNOWLEDGEMENTS}

We acknowledge the invaluable contributions of $P$. Beech, E.D. Clark, M. Pelletier, and F. Smith, all members of the Geophysics Section, NSRFC, who carried out the geophysical surveys. Members of the analytical laboratory, NSRFC are thanked for carrying out the rock sample chemical analyses. We also thank Environment Canada for permission to publish the survey results. The manuscript was considerably improved as a result of constructive comments by reviewers Dr. H.G. Miller and Dr. J. Colwell, and journal editor Sandra Barr.

Albright, R. 1987. Prediction of Acid Drainage in Meguma Slates. In Proceedings, Acid Mine Drainage Seminar/Workshop, Halifax, Nova Scotia, March 23-26, 1987. Environment Canada, pp. 245-261.

American Society for Testing and Materials. 1990. D2492 Standard Test Method for Forms of Sulphur in Coal. Annual Book of ASTM Standards, Volume 05.05, pp. 251-256.

BruYnesteyn, A. and Duncan, D.W. 1979. Determination of acid production potential of waste materials. Metallurgical Society AIME, Paper A-79-29, 10 p.

Dunlop, D.J. and Ozdemir, O. 1997. Rock Magnetism. Cambridge University Press, pp. 77-79.

ENVIRonment Act S.N.S. 1994-95, c.1, section 66. Order in Council 95-296 (April 11, 1995), N.S. Reg. 57/95, 7 p.

FARIBAULt, E.R. 1909. Waverley Sheet, Geological Survey of Canada, Map 67.

Feetham, M., Ryan, R.J., Pe-Piper, G., and O'Beirne-Ryan, A.M. 1997. Lithogeochemical characterization of the Beaverbank unit of the Halifax Formation, Meguma Group, and acid drainage implications. Atlantic Geology, 33, pp. 133-141.

Fox, D., Robinson, C., and Zentilli, M. 1997. Pyrrhotite and associated sulphides and their relationship to acid rock drainage in the Halifax Formation, Meguma Group, Nova Scotia. Atlantic Geology, 33, pp. 87-103.

Fraser, D.C. 1969. Contouring of VLF-EM data. Geophysics, 34, pp. 958-967.

Grological Survey of Canada. Aeromagnetic Series Maps 790G and $785 \mathrm{G}, 1960$.

GOLDER AssOcIaTEs. 1983. Subsurface Investigation Definition of Slate/Quartzite Contact, Part of Phase 1, Aerotech Business Park, Halifax County, Nova Scotia. Unpublished Consultant Report.

Heiland, C.A. 1963. Geophysical Exploration. Hafner Publishing Company, New York and London, 1013 p.

Hennigar, T.W. and GiBB, J.E. 1987. Surface and groundwater impacts of acid mine drainage from the Meguma slates of Nova Scotia. In Proceedings, Acid Mine Drainage Seminar/ Workshop, Halifax, Nova Scotia, March 23-26, 1987. Environment Canada, pp. 165-187.

Hingston, R.W. 1985. The manganiferous slates of the CambroOrdovician Meguma Group at Lake Charlotte, Halifax County, Nova Scotia. B.Sc. Honours thesis, Dalhousie University, Halifax, Nova Scotia, 67 p.

Howells, K. and McKAY, A.G. 1985. A Total Magnetic Field and Seismic Survey over a Possible Dam Site at Bennery Lake, Halifax County, N.S. Nova Scotia Research Foundation Corporation Report for Nolan, Davis and Associates. 
JACQUES, Whit FoRd AND Associates. 1981. Soil Investigation-Proposd Airport Industrial Park, Halifax County, Nova Scotia. Unpublished Consultant Report.

KING, M.S. 1997. Magnetic susceptibility mapping: applications for the Meguma Group, central Nova Scotia. Atlantic Geology, 33, pp. 121-131.

KING, M. and HART, W. 1990. Groundwater contribution to acid drainage from the Halifax Formation in Nova Scotia. Canadian Water Resources Journal, 15, pp. 357-365.

Klein, C. and Hurlbur, C.S. 1993. Manual of Mineralogy. John Wiley and Sons, Inc., p. 235.

Lund, O.P., Vaughan, J., and Thirumurthi, D. 1987. Impact of acid drainage pollution from mineralized slate at Halifax airport. Water Pollution Resources Journal of Canada, 2, pp. 308-325.

MacInNIs, I.N. 1986. Lithogeochemistry of the Goldenville-Halifax transition (GHT) of the Meguma Group in the manganiferous zinc-lead deposit at Eastville, Nova Scotia. B.Sc. Honours thesis, Dalhousie University, Halifax, Nova Scotia, 138 p.

$\mathrm{McG}_{\mathrm{RATH}}$, P.H. 1970. Aeromagnetic interpretation Appalachia, New Brunswick and Nova Scotia (11D, E, F, K; 20O, P; 21 A, G, H, J). Geological Survey of Canada, Paper 70-1A, pp. 79-82.

MCNEILL, J.D. 1980. Electromagnetic terrain conductivity measurement at low induction numbers. Technical Note TN-6, Geonics Limited, $15 \mathrm{p}$.

Mine Environment Neutral Drainage (MEND). 1991. New Methods for Determination of Key Mineral Species in Acid Generation Prediction by Acid-Base Accounting. MEND Project 1.16.1c

Nettleton, L.L. 1940. Geophysical Prospecting for Oil. McGrawHill Book Company, Inc., 444 p.

Nicholson, R.V. and Scharer, J.M. 1994. Laboratory studies of pyrrhotite oxidation kinetics. In Environmental Geochemistry of Sulphide Oxidation. Edited by Charles N. Alpers and David W. Blowes. American Chemical Society, Washington D.C., pp. 14-30.

Nolan, Davis and Associates. 1983. Acidic Drainage Study for the Aerotech Business Park. Unpublished Consultant Report.

Nova Scotia Research Foundation Corporation. 1985a. Test Geophysical Methods to detect Shallow Sulphide Mineralization in Cambro-Ordovician Slates near Halifax International Airport, Nova Scotia. Nova Scotia Research Foundation Corporation, Report 1-85, 23 p.

-.--1 1985b. The Evaluation of Some Geophysical Methods for the Detection Shallow Sulphide Mineralization. Nova Scotia Research Foundation Corporation, Final Report 5-85, 51 p.
Parasnis, D.S. 1986. Principles of Applied Geophysics. Chapman and Hall, New York, New York, 402 p.

Pasava, J., Graves, M.C., MacInnis, I.N., and Zentilli, M. 1995. Black slates - A source of acid drainage at the Halifax International Airport, Nova Scotia, Canada. In Mineral Deposits: From their origin to their environmental impacts. Proceedings of the Third Biennial SGA Meeting, Prague, Czech Republic, August 28-31, 1995, pp. 785-788.

Petripas, B. 1979. A statistical evaluation of the effect of acid leachate on water quality, in Union Square, Lunenburg County. Nova Scotia Department of Environment Report, June, 1979, $56 \mathrm{p}$.

Pratt, A.R., Muir, I.J., and Nesbitt, H.W. 1994. X-ray photoelectron and Auger electron spectroscopic studies of pyrrhotite and mechanism of air oxidation. Geochimica et Cosmochimica Acta, 51:2, pp. 827-841.

PrICE, W.A. 1997. Guidlines and recommended methods for the prediction of metal leaching and acid rock drainage at minesites in British Columbia (draft). Ministry of Employment and Investment, Smithers, British Columbia, $151 \mathrm{p}$.

Samostie, A. 1994. Assessment of Acid Mine Drainage Risk in Nova Scotia: An Application of Geographic Information Systems (GIS). Master of Environmental Studies thesis, Dalhousie University, Halifax, Nova Scotia, 180 p.

SANGster, A.L. 1990. Metallogeny of the Meguma Terrane, Nova Scotia. In Mineral Deposit Studies in Nova Scotia, Volume 1. Edited by A.L. Sangster. Geological Survey of Canada, Paper 90-8, pp. 115-162.

Schwarz, E.J. and Broome, J. 1994. Magnetic Anomalies due to pyrrhotite in Paleozoic metasediments in Nova Scotia, Eastern Canada. Journal of Applied Geophysics, 32, pp. 1-10.

Schwarz, E.J. and McGrath, P.H. 1974. Aeromagnetic anomalies related to pyrrhotite occurrences in the Canadian Appalachian region. Geological Survey of Canada, Paper 74-1, Current Research, Part B, pp. 107-108.

Sobek, A.A., Schuller, W.A., Freeman, J.R., and Smith, R.M. 1978. Field and laboratory methods applicable to overburdens and minesoils. Environmental Protection Agency Report 600/2-78-054, $203 \mathrm{p}$.

Telford, W.M., Geldart, L.P., Sheriff, R.E., and Keys, D.A. 1976. Applied Geophysics. Cambridge University Press, 860 p.

Worgan, J. 1987. Acid mine drainage in reactive slates, "The Halifax International Airport Case" Transport Canada perspective. In Proceedings, Acid Mine Drainage Seminar/Workshop, Halifax, Nova Scotia, March 23-26, 1987. Environment Canada, pp. 127-135.

Editorial Responsibility : S.M. Barr 